\title{
十字形断面をもつ座屈拘束ブレース接合部の 構面外曲げ剛性と降伏曲げ耐力 \\ OUT-OF-PLANE STIFFNESS AND YIELD STRENGTH OF CRUCIFORM CONNECTION FOR BUCKLING-RESTRAINED BRACE
}

\author{
木下智裕*, 聲高裕治**, 井上一朗***, 飯谷邦 祐**** \\ Tomohiro KINOSHITA, Yuji KOETAKA, Kazuo INOUE \\ and Kunihiro IITANI
}

\begin{abstract}
In order to prevent out-of-plane buckling of buckling-restrained brace, its connections must have enough out-ofplane stiffness and be kept elastic. This paper deals with out-of-plane stiffness and yield strength of bucklingrestrained brace's connection whose section is cruciform. Firstly, methods of calculating both out-of-plane stiffness and yield strength of connection are proposed by means of RBSM. And secondly, experimental verifications to load connection specimens were conducted. As a result, it is clarified that out-of-plane stiffness is very small if finstiffener is not connected to beam-flange. Therefore, it is recommended that fin-stiffener should be welded to beamflange to satisfy required out-of-plane stiffness and yield strength.
\end{abstract}

Keywords : Buckling-restrained Brace, Connection, Out-of-plane Stiffness, Yield Strength, Loading Test 座屈拘束ブレース，接合部，構面外剛性，降伏耐力，載荷実験

\section{1. 序}

座屈拘束ブレースは, 図 1 に示すように芯材の周囲を座屈拘束材 で覆っている座屈拘束部, および柱や梁との接合部から構成される. 本研究は, このような座屈拘束ブレースの構面外座屈を防止する設 計法の構築をめざしている。これまでに, 接合部を含む座屈拘束ブ レースの構面外座屈防止条件を提示し $\left.{ }^{1)}, 2\right)$, その妥当性を実験的に 確認している ${ }^{2)}$. ただし,これらの研究では, 接合部は弾性を維持し, 接合部の構面外剛性は既知であることを前提条件としている。

接合部は，本論 2 章で詳述するように，ガセットプレート接合部 （図 1 のグレーのハッチ領域）と接合部母材，およびそれらを接合

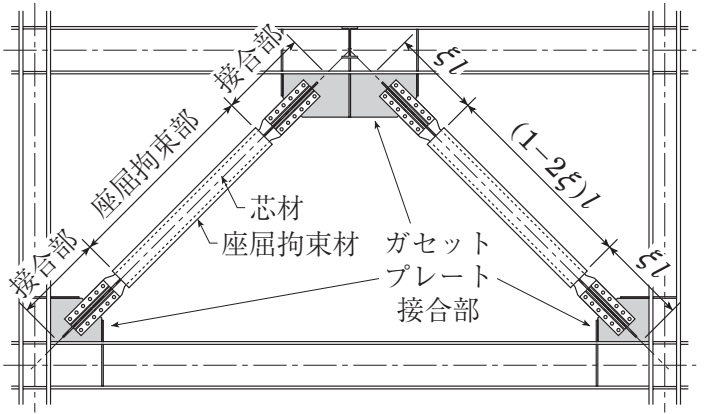

図 1 座屈拘束ブレース
するための添板で構成される変断面材である. 座屈拘束ブレースの 構面外座屈を検討する過程では，このように複雑な形状の接合部の 構面外剛性を算定しなければならない.

また接合部には，図 2 の $\mathrm{A}$ 断面に示すように直交構面の層間変 形や不可避の偏心等に伴って偏心圧縮軸力が作用する。芯材の塑性 化に伴って座屈拘束部の両端がヒンジとみなせる条件下 ${ }^{2)}$ では, 偏 心圧縮軸力に対してガセットプレート接合部や添板が塑性化する と, 座屈拘束ブレースが不安定状態となるため, 接合部は弾性を維 持するように設計しなければならない.

ガセットプレート接合部の構面外剛性および降伏曲げ耐力の算定

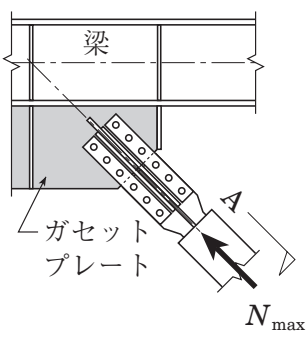

図 2 接合部の設計応力（構面外）

\footnotetext{
本論文の一部は，日本建築学会近畿支部研究報告集，第47号・構造系(2007.6)に発表している。

* JFE スチール(株建材センター 部員・修士(工学)

** 大阪工業大学工学部建築学科 講師 · 博士 (工学)

*** 京都大学大学院丁学研究科建築学専攻 教授.丁博

**** JFE スチール(株)西日本製鉄所 主任部員・修士(工学)

Staff, Construction Materials \& Services Center, JFE Steel Corporation, M. Eng. Lecturer, Dept. of Architecture, Osaka Institute of Technology, Dr. Eng.

Prof., Dept. of Architecture and Architectural Engineering, Kyoto University, Dr. Eng. Staff Deputy Manager, West Japan Works, JFE Steel Corporation, M. Eng.
} 


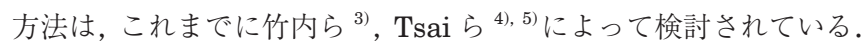
たたし,これらの研究で対象としているガセットプレート接合部は, 本論で対象としている図 3 のガセットプレート接合部 (2 章参照) とは異なる.

本論では，図 3 に示すガセットプレート接合部を対象として，ま ずは K ブレース交点側のガセットプレート接合部の構面外剛性と 降伏曲げ耐力（ほぼ弾性とみなすことができる接合部の限界曲げ耐 力）を，ガセットプレート接合部の形状や板厚などの幾何学的情報 に基づいて簡易に算定する方法を提案する。提案した算定法に基づ くガセットプレート接合部の構面外剛性と降伏曲げ耐力の予測結果 と, 座屈拘束ブレース接合部の載荷実験結果を比較・考察する。ま た, 柱梁接合部側のガセットプレート接合部についても, K ブレー ス交点側のガセットプレート接合部と同様の方法で構面外剛性と降 伏曲げ耐力を算定できることを示す．最終的には，芯材の塑性化に 伴って座屈拘束部の両端がヒンジとみなせる場合を対象として, 四 2 に示すように直交構面の層間変形や不可避の偏心等に伴う偏心圧 縮軸力に対して，接合部を弾性に保つための設計法を提案する。な お，ガセットプレートが接合される柱や梁には，ガセットプレート 接合部に作用する応力を伝達するため ${ }^{6)} に$, スチフナが適切に配置 されていることを前提とする。

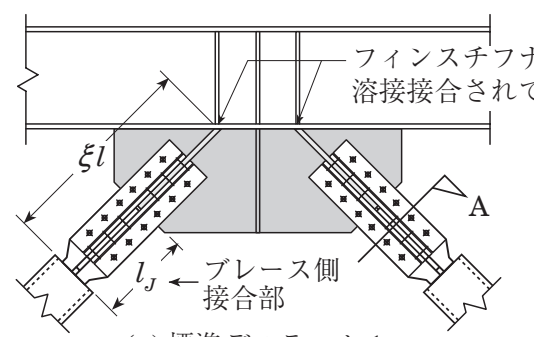

(a) 標準ディテール 1

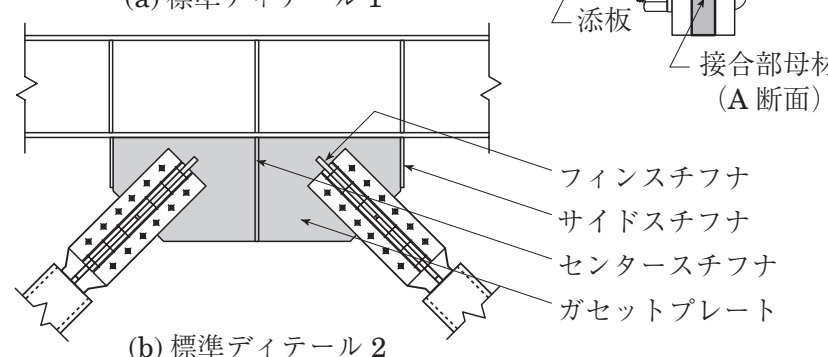

(b) 標準ディテール 2

図 3 ガセットプレート接合部の形状と名称

\section{2. ガセットプレート接合部の形状}

図 3 に，ガセットプレート接合部各部の名称を示す。フィンスチ フナは, 高力ボルト接合用に座屈拘束ブレース材軸と平行に設けら れる構面外スチフナプレートであり，サイドスチフナとセンタース チフナは，ガセットプレートの構面外剛性を高めるために設置され るスチフナプレートである。これらのスチフナプレートを含まない 板材を単にガセットプレートと呼ぶ. また, 接合部のうち, 図 3 中 の長さ $l_{J}$ の区間をブレース側接合部と呼び， $\mathrm{A}$ 断面において添板 を含まない十字断面を接合部母材と呼ぶ.

本論では図 3 に示す 2 種類のガセットプレート接合部を対象とす る. 図 3 (a) に示す標準ディテール 1 は，フィンスチフナが梁フラ ンジに溶接接合されている場合である. 図 3 (b) に示す標準ディテー ル 2 は,フィンスチフナが梁フランジまで到達していないが, ガセッ トプレートがサイドスチフナによって補強されている場合である. 標準ディテール 1 では，ガセットプレート接合部の構面外剛性と降 伏曲げ耐力は接合部母材のそれぞれと等しいとすれば，どちらも過 小評価になる。しかし，標準ディテール 2 の場合には，ガセットプ レート接合部の構面外剛性と降伏曲げ耐力は, 接合部母材と同等以 上であるとはいえない. 本論では, 標準ディテール 2 を対象として, ガセットプレート接合部の構面外剛性と降伏耐力の算定方法を提案 する。

\section{Kブレース交点側ガセットプレート接合部の構面外剛性と降伏耐カ} 3. 1 剛体一バネモデル

本章では, 図 3 (b) を対象として K ブレース交点側のガセットプ

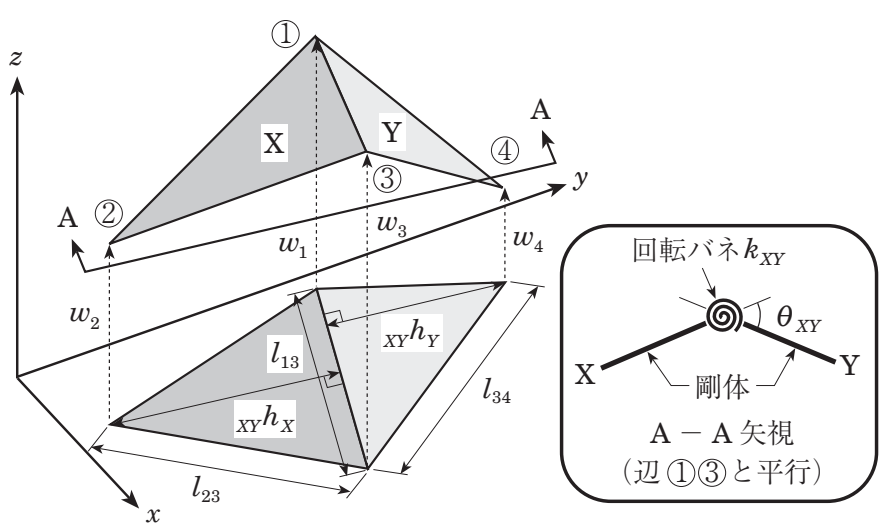

図 4 剛体一バネモデルの概要

表 1 剛性マトリックス $\boldsymbol{K}_{X Y}$ の成分 $\left(\times k_{X Y}\right)$

\begin{tabular}{|c|c|c|c|c|}
\hline & $w_{1}$ & $w_{2}$ & $w_{3}$ & $w_{4}$ \\
\hline$P_{1}$ & $\left(\frac{\sqrt{l_{23}^{2}-{ }_{X Y} h_{X}^{2}}}{l_{13 X Y} h_{X}}+\frac{\sqrt{l_{34}^{2}-{ }_{X Y} h_{Y}^{2}}}{l_{13 X Y} h_{Y}}\right)^{2}$ & 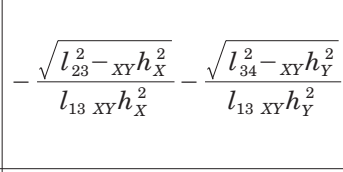 & $\begin{array}{l}\left(\frac{\sqrt{l_{23}^{2}-{ }_{X Y} h_{X}^{2}}}{l_{13 X Y} h_{X}}+\frac{\sqrt{l_{34}^{2}-{ }_{X Y} h_{Y}^{2}}}{l_{13 X Y} h_{Y}}\right) \\
\cdot\left\{\frac{1}{X Y} h_{X}\left(1-\frac{\sqrt{l_{23}^{2}-X Y} h_{X}^{2}}{l_{13}}\right)+\frac{1}{X Y} h_{Y}\left(1-\frac{\sqrt{l_{34}^{2}-{ }_{X Y} h_{Y}^{2}}}{l_{13}}\right)\right\}\end{array}$ & $-\frac{\sqrt{l_{23}^{2}-{ }_{X Y} h_{X}^{2}}}{l_{13 X Y} h_{X X Y} h_{Y}}+\frac{\sqrt{l_{34}^{2}-{ }_{X Y} h_{Y}^{2}}}{l_{13 X Y} h_{Y}^{2}}$ \\
\hline$P_{2}$ & & $\frac{1}{{ }_{X Y} h_{X}^{2}}$ & $-\frac{1}{X Y} h_{X}^{2}\left(1-\frac{\sqrt{l_{23}^{2}-{ }_{X Y} h_{X}^{2}}}{l_{13}}\right)-\frac{1}{X Y h_{X X Y} h_{Y}}\left(1-\frac{\sqrt{l_{34}^{2}-{ }_{X Y} h_{Y}^{2}}}{l_{13}}\right)$ & $\frac{1}{{ }_{X Y} h_{X X Y} h_{Y}}$ \\
\hline$P_{3}$ & & & $\left\{\frac{1}{X Y} h_{X}\left(1-\frac{\sqrt{l_{23}^{2}-X Y} h_{X}^{2}}{l_{13}}\right)+\frac{1}{X Y} h_{Y}\left(1-\frac{\sqrt{l_{34}^{2}-X Y} h_{Y}^{2}}{l_{13}}\right)\right\}^{2}$ & 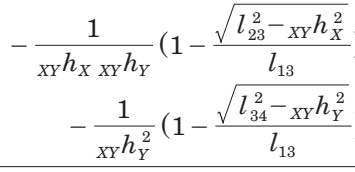 \\
\hline$P_{4}$ & & & & $\frac{1}{X Y} h_{Y}^{2}$ \\
\hline
\end{tabular}




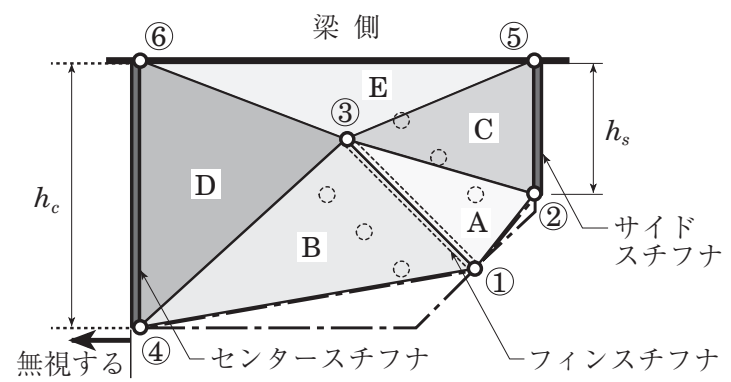

図 5 解析モデル

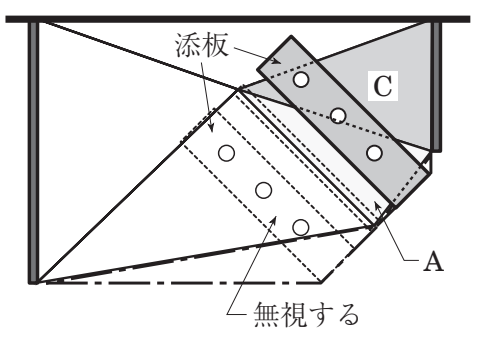

図 6 添板の効果

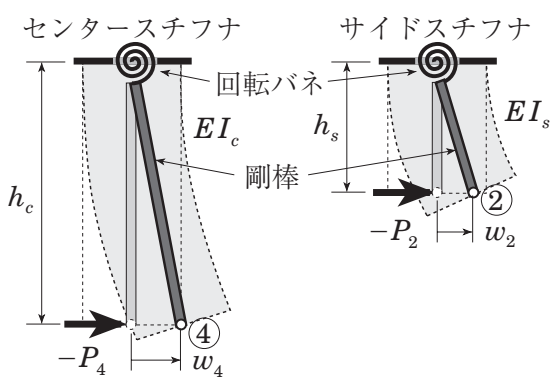

図 7 スチフナの構面外変形
レート接合部の構面外剛性と降伏耐力を，剛体一バネモデル ${ }^{7)}$ (以

下，RBSM と略記する）を用いて算定する方法を構築する。簡単 のため, ガセットプレート接合部は 2 次元部材として扱い, せん断 変形は無視する．以下に文献 7) に従い，RBSM の概略を示す。

RBSM では板要素を複数の三角形要素に分割する. 図 4 に示す ように, 隣り合う三角形要素 $(\mathrm{X}$ と $\mathrm{Y})$ を取り出して考える. 各三 角形要素は剛体とし，その境界に設けられた回転バネで連結されて いる. 回転バネ剛性 $k_{X Y}$ は次式で与えられる (寸法記号は図 4 参照).

$$
k_{X Y}=\frac{2 l_{13}}{X_{X Y} h_{X}+_{X Y} h_{Y}} \cdot \frac{E t^{3}}{12\left(1-v^{2}\right)}
$$

ただし， $t$ は三角形要素の板厚，vはポアソン比である.

図 4 に示すように各三角形要素は $z$ 方向（構面外方向）のみに移 動可能とする.このとき, 回転バネの回転角 $\theta_{X Y}$ は各節点の構面外 変位 $w_{1} \sim w_{4}$ を用いて表すことができ, 各節点に作用する構面外 荷重を $P_{1} \sim P_{4}$ とすると, 剛性方程式は次式で与えられる.

$$
\left\{P_{1}, P_{2}, P_{3}, P_{4}\right\}^{\mathrm{T}}=\boldsymbol{K}_{\boldsymbol{X Y}}\left\{w_{1}, w_{2}, w_{3}, w_{4}\right\}^{\mathrm{T}}
$$

ここで, $\boldsymbol{K}_{X Y}$ は三角形要素 X と Y の要素境界に関する剛性マトリッ クスであり， $\boldsymbol{K}_{X Y}$ の成分は表 1 に示すように図 4 の各三角形要素の 寸法を用いて表される。これらの寸法は，図 5 における(1)〜(6)座 標から算定される (付録 1 参照).

\section{2 ガセットプレート接合部のモデル化}

図 5 に示すように，Kブレース交点側のガセットプレート接合部 の半分を取り出してモデル化する．図 5 で一点鎖線で囲った三角形 領域は，ガセットプレート接合部の構面外剛性と降伏耐力に影響を 与えないものとして無視し，その他の領域を図 5 に示すように $5 つ$ の三角形要素 $(\mathrm{A} \sim \mathrm{E})$ に分割する. 節点(1)と節点(3)はフィンスチ フナの両端部に位置し, 節点(2)と節点(4)はそれぞれサイドスチフナ とセンタースチフナに連結されている. 各三角形要素は, 辺(2)(5), 辺(4)(6)，辺(5)(6に打いて各辺まわりの回転を拘束されているものと する. フィンスチフナ, 溶接部の余盛, ボルト孔欠損は無視する.

ガセットプレート接合部と接合部母材は, 添板を介し て高力ボルト摩擦接合されるが, 図 5 の解析モデルでフィ ンスチフナは剛体移動するだけであるので, フィンスチフ ナにとりつく添板は無視する。また，ガセットプレート にとりつく添板のうち, 図 6 に示すように, 上側の添板 (白抜き) はガセットプレート接合部の構面外挙動に与え る影響は小さいと考えられるので無視し, 下側の添板（色 つき) だけを考慮する。この添板は三角形要素 $\mathrm{A}$ と C の 境界に位置するので, その境界に扔ける回転バネ剛性 $k_{A C}$ にその効果を反映させる，ただし，ガセットプレートと
添板からなる断面は, 平面保持が成立しないものと考える。回転バ ネ剛性 $k_{A C}$ の算定式は次節 $((9 . \mathrm{b})$ 式）で示す.

\section{3 ガセットプレート接合部の構面外剛性}

図 5 の解析モデルにおいて節点(5)，(6)が不動点であることを考慮 すると, 節点(i)の構面外荷重 $P_{i}$ と構面外変位 $w_{i}$ の関係は, 全体剛 性マトリックスを $\boldsymbol{K}_{\boldsymbol{G}}$ として次式で与えられる.

$$
\left\{P_{1}, P_{2}, P_{3}, P_{4}\right\}^{\mathrm{T}}=\boldsymbol{K}_{\boldsymbol{G}}\left\{w_{1}, w_{2}, w_{3}, w_{4}\right\}^{\mathrm{T}}
$$

$\boldsymbol{K}_{\boldsymbol{G}}$ は, 図 5 で隣り合う三角形要素 $(\mathrm{A}$ と $\mathrm{B}, \mathrm{A}$ と $\mathrm{C}, \mathrm{B}$ と D, C と $\mathrm{E}$, $\mathrm{D}$ と $\mathrm{E})$ ついて, 3.1 節の方法によって求めた要素境界に関する剛 性マトリックスを，(3) 式中の対応する自由度に重ね合わせること で求められる。

節点(3には構面外荷重が作用しないため, $P_{3}=0$ である. また, サイドスチフナとセンタースチフナは, 図 7 に示すように回転バネ と剛棒でモデル化し, 節点(2)と節点(4)の構面外変位 $w_{2}, w_{4}$ が, サ イドスチフナとセンタースチフナを上端固定の片持ち梁とみなした ときの曲げ変形と等しくなるように回転バネの剛性を定める。サイ ドスチフナ下端（節点(2)）に節点反力 $-P_{2}$ が，センタースチフナ 下端（節点(4)）に節点反力 $-P_{4}$ が作用すると考えれば，構面外変 位 $w_{2}, w_{4}$ はそれぞれ次式で表される.

$$
w_{2}=-\frac{h_{s}^{3}}{3 E I_{s}} P_{2}, \quad w_{4}=-\frac{h_{c}^{3}}{3 E I_{c}} P_{4}
$$

ただし, $E I_{s}$ はサイドスチフナの構面外曲げ剛性, $E I_{c}$ はセンター スチフナの構面外曲げ剛性である.

以上より，(3) 式の全体剛性マトリックス $\boldsymbol{K}_{\boldsymbol{G}}$ は節点(1)の自由度 だけに縮約して表すことができ，節点(1)に作用する構面外荷重 $P_{1}$ と節点(1)の構面外変位 $w_{1}$ の比をガセットプレート接合部の構面外 剛性 $K_{G}$ と定義すると， $K_{G}$ は次式で与えられる.

$$
K_{G}={ }_{G} K_{11}-\left(\lambda_{2} \cdot{ }_{G} K_{12}+\lambda_{3} \cdot{ }_{G} K_{13}+\lambda_{4} \cdot{ }_{G} K_{14}\right)
$$

ただし，上式で ${ }_{G} K_{11},{ }_{G} K_{12},{ }_{G} K_{13},{ }_{G} K_{14}$ は全体剛性マトリックス

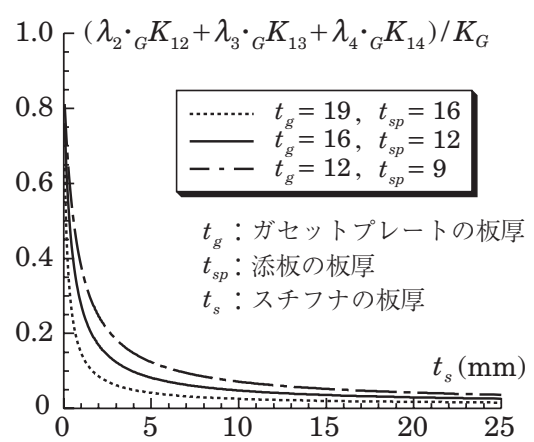

図 8 構面外剛性とスチフナの板厚 $t_{s}$

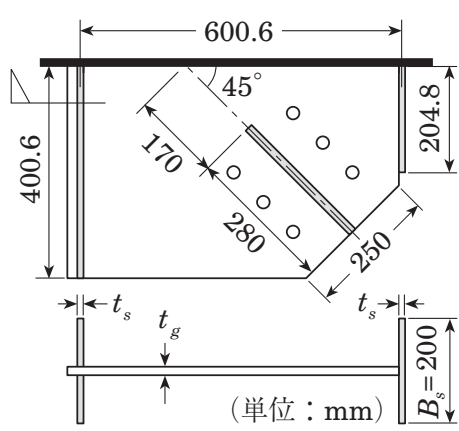

図 9 検討対象ディテール 
$\boldsymbol{K}_{\boldsymbol{G}}$ の第 1 行の成分であり， $\lambda_{2}, \lambda_{3}, \lambda_{4}$ はそれぞれ次式を満足する 係数である.

$$
\lambda_{2}=-w_{2} / w_{1}, \quad \lambda_{3}=-w_{3} / w_{1}, \quad \lambda_{4}=-w_{4} / w_{1} \quad(6 . \mathbf{a}) \sim(6 . \mathbf{c})
$$

図 8 にガセットプレートの板厚 $t_{g}$ をパラメータとして, (5) 式の 右辺第 2 項〜第 4 項の和と, サイドスチフナ・センタースチフナの 板厚 $t_{s}$ との関係を示す。ただし, 縦軸は (5) 式の $K_{G}$ で無次元化し ている. 対象とするガセットプレート接合部は図 9 に示すものであ る.これは, ガセットプレートの板厚 $t_{g}$ が $16 \mathrm{~mm}$ の場合に, 後述 の載荷実験の試験体 No.2 と同一であり，降伏軸力が $1500 \mathrm{kN}$ 程度 の座屈拘束ブレースの接合部に相当する．添板の板厚 $t_{s p}$ は， $t_{g}$ の ワンサイズダウンとした。

図 8 より, 各スチフナの板厚 $t_{s}$ がガセットプレートの板厚 $t_{g}$ と 同程度であり, 幅 (奥行き) $B_{s}$ が梁フランジ幅程度（図 8 では $B_{s}$ $=200 \mathrm{~mm}$ とした）確保されていれば，縦軸の值は高々数％程度で あり，(5) 式の右辺第 2 項以降は無視できるといえる。すなわち， 節点(2), (3), (4)は構面外に移動しないものと考え, ガセットプレー 卜接合部の構面外剛性 $K_{G}$ は次式で略算できる（各寸法記号は図 4 参照).

ここで,

$$
K_{G}={ }_{G} K_{11}={ }_{A B} K_{11}+{ }_{A C} K_{11}+{ }_{B D} K_{11}
$$

$$
\begin{aligned}
& { }_{A B} K_{11}=k_{A B} \cdot\left(\frac{\sqrt{l_{23}^{2}-{ }_{A B} h_{A}^{2}}}{l_{13}{ }_{A B} h_{A}}+\frac{\sqrt{l_{34}^{2}-{ }_{A B} h_{B}^{2}}}{l_{13}{ }_{A B} h_{B}}\right)^{2} \\
& { }_{A C} K_{11}=k_{A C}{ }_{A C} h_{A}^{2},{ }_{B D} K_{11}=k_{B D} /_{B D} h_{B}^{2} \\
& k_{A B}=\frac{2 l_{13}}{{ }_{A B} h_{A}{ }_{A B} h_{B}} \cdot \frac{E t_{g}^{3}}{12\left(1-v^{2}\right)} \\
& k_{A C}=\frac{2 l_{23}}{{ }_{A C} h_{A}{ }_{A C} h_{C}} \cdot \frac{E\left(t_{g}^{3}+2 t_{s p}^{3}\right)}{12\left(1-v^{2}\right)} \\
& k_{B D}=\frac{2 l_{34}}{{ }_{B D} h_{B}{ }_{B D} h_{D}} \cdot \frac{E t_{g}^{3}}{12\left(1-v^{2}\right)}
\end{aligned}
$$

以降, $K_{G}$ は (7) 式の略算式により算出する.

\section{4 座屈拘束ブレース接合部の曲げ剛性 $E I_{J}^{*}$}

座屈拘束ブレースの接合部は, 図 3 に示すように,ガセットプレー 卜接合部と接合部母材，およびそれらを接合するための添板からな る変断面材である。しかし，接合部を含む座屈拘束ブレースの構面 外座屈荷重 ${ }^{1,2}$, を求めるためには, 接合部を一様な曲げ剛性をもつ 線材に置換する必要がある。そこで, 図 10 (a)に示すように, 座屈 拘束ブレースの接合部全体を構面外曲げ剛性 $E I_{J}^{*}$ をつ長さ $\xi l$ の 線材にモデル化する.

接合部の構面外曲げ剛性 $E I_{J}^{*}$ を求めるために, 図 11 に示すよう
に芯材と接合部との境界位置（図中 o印）に構面外荷重 $P$ が作用 した場合を考え，ガセットプレート接合部の構面外挙動を図 $10(\mathrm{~b})$ に示すようにモデル化する。すなわち，フィンスチフナと梁フラン ジとの隙間（長さ $l_{N F}$ ) およびフィンスチフナを剛とし，これらの 2 本の剛棒の間に $K_{G} l_{F}^{2}$ の剛性を有する回転バネを設ける。これは, 3.3 節で述べたように，RBSM ではセンタースチフナとサイドスチ フナが設置されている場合, 節点(3)の構面外変位が無視できること に基づいている.

以上より, 芯材と接合部の境界（図 10 の右端）に構面外荷重 $P$ が作用したとき，その位置の構面外変位 $w$ を図 10 (a) と図 $10(\mathrm{~b})$ で等置して, 接合部の構面外曲げ剛性 $E I_{J}^{*}$ を次式で与える.

$$
E I_{J}^{*}=\frac{(\xi l)^{3}}{3\left\{\left(l_{J}+l_{F}\right)^{2} /\left(K_{G} l_{F}^{2}\right)+l_{J}^{3} /\left(3 E I_{J}\right)\right\}}
$$

ただし，EIJ は接合部母材の構面外曲げ剛性である.

\section{5 ガセットプレート接合部の降伏曲げ耐カ}

座屈拘束ブレース芯材と接合部の境界に構面外荷重 $P$ が作用し たとき，ガセットプレート接合部端部には $P \cdot \xi l の$ 曲げモーメント が作用する。ガセットプレート接合部の曲げ剛性が線形を維持でき る限界の曲げモーメントを接合部の降伏曲げ耐力と定義し, 本節で は 2 種類の降伏曲げ耐力の算出方法を提示する.

まず 1 つ目は, サイドスチフナとセンタースチフナの構面外の曲 げ耐力が十分大きい場合であり，図 12 左側に示す崩壊機構を想定 する，図中の太線は，図 5 に示す RBSM を用いた解析モデルにお ける三角形要素 $\mathrm{A}$ と B の境界線であり,これらを降伏線とみなすと, 接合部の降伏曲げ耐力 ${ }_{G} M_{y}$ は次式で与えられる.

$$
\begin{aligned}
{ }_{G} M_{y}= & { }_{G} P_{y} \cdot \xi l \\
{ }_{G} P_{y}= & \left(\frac{\sqrt{l_{23}^{2}-{ }_{A B} h_{A}^{2}}}{{ }_{A B} h_{A}}+\frac{\sqrt{l_{34}^{2}-{ }_{A B} h_{B}^{2}}}{{ }_{A B} h_{B}}+\frac{l_{23}}{{ }_{A C} h_{A}}+\frac{l_{34}}{{ }_{B D} h_{B}}\right) \\
& \cdot \frac{l_{F}}{l_{F}+l_{J}} \cdot \frac{t_{g}^{2} \sigma_{g y}}{6}
\end{aligned}
$$

ただし， $\sigma_{g y}$ はガセットプレートの降伏応力である．また，添板と ガセットプレートからなる断面は平面保持が成立しないと考えられ るので，降伏曲げ耐力の算出では添板を無視する.

もう 1 つは, サイドスチフナの曲げ耐力が小さい場合に相当する. このとき, 図 12 左側の機構が形成される前にサイドスチフナが曲 げ降伏し，ガセットプレート接合部の構面外曲げ剛性が低下する. 図 12 右側に示すように接合部に作用する曲げモーメントをすべて サイドスチフナが負担すると考えれば，ガセットプレート接合部の 降伏曲げ耐力 ${ }_{S} M_{y}$ は, 図 12 の記号を参照して次式で与えられる.

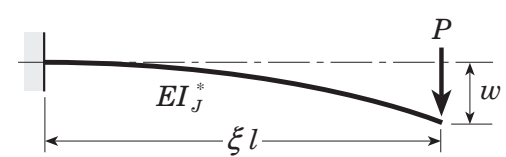

(a)

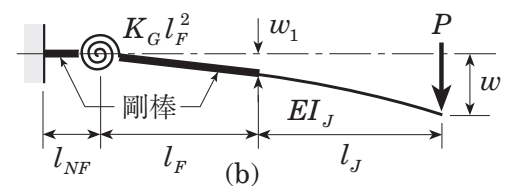

図 10 接合部のモデル化

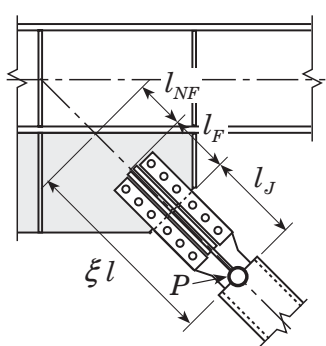

図 11 構面外荷重の作用位置

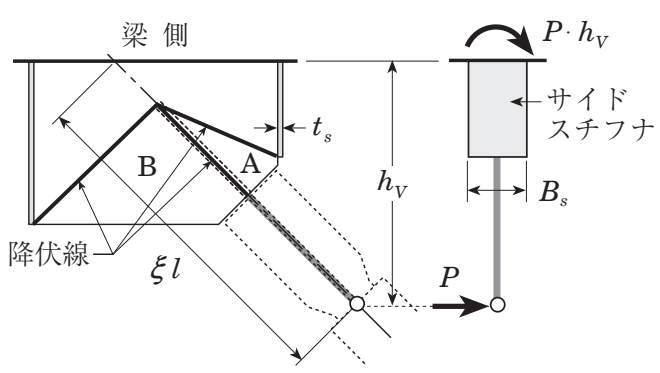

図 12 降伏曲げ耐力の求め方 


$$
\begin{aligned}
& { }_{S} M_{y}={ }_{S} P_{y} \cdot \xi l \\
& { }_{S} P_{y}=\frac{B_{s}^{2} t_{s} \sigma_{s y}}{6 h_{V}}
\end{aligned}
$$

ただし， $\sigma_{s y}$ はサイドスチフナの降伏応力である.

\section{4. ガセットプレート接合部の載荷実験}

本章では，ガセットプレート接合部の構面外剛性と降伏曲げ耐力 について，3 章で示した算定法に基づく計算結果と実験結果を比較 する。

\section{1 試験体と実験パラメータ}

試験体は, 図 13 に示すようにKブレース交点側のガセットプレー 卜接合部の半分を取り出したものであり，ガセットプレート接合部 とブレース側接合部母材，それらを接合するための添板で構成され る。なお，試験体の最下部に溶接された $\mathrm{PL}-40$ の鋼板を高力ボル トによって鋼製ジグに緊結しているため, 3 章までに示した図(図 3, 図 5, 図 6）と比べると上下が入れ替わっている.

表 2 に試験体一覧を(各記号は図 13 参照), 表 3 に使用鋼材の 機械的性質を示す．試験体 No.1 はフィンスチフナが梁フランジま で到達している試験体（標準ディテール 1 ：図 3(a) 参照）であり, 試験体 No.2 No.9 は到達していない試験体（標準ディテール 2 ： 図 3(b) 参照) である。フィンスチフナが梁フランジまで到達して いない試験体のうち, 試験体 No.2 を基準試験体とする。実験パラ メータは, サイドスチフナの構面外剛性（No.3, No.9), ガセット プレートの板厚 $t_{g}$ (No.4), フィンスチフナと梁フランジとの隙間 $l_{N F}$ (No.4 と No.5 の比較), K ブレースの交点位置 (No.6), ブレー スの取付角度 $\phi$ (No.7), ボルト列数（No.8）である.

\section{2 実験概要}

実験では, 載荷点（図13の○）を油圧ジャッキで構面外方向に 単調載荷する。ガセットプレート接合部の構面外剛性を確認するた めに, 載荷点 (図 13 の ○) の構面外荷重 $P$ とフィンスチフナ上端 (図 13 の）の構面外変位 $w_{1}$ を計測する. 構面外荷重 $P$ と構面外変位 $w_{1}$ の比を構面外剛性 $K_{G}^{*}$ と定義し, $K_{G}^{*}$ の実験值を ${ }_{\exp } K_{G}^{*}, \mathrm{RBSM}$ による計算值を ${ }_{c a l} K_{G}^{*}$ と記す。なお， ${ }_{c a l} K_{G}^{*}$ は次式に従って求める.

$$
{ }_{c a l} K_{G}^{*}=K_{G} l_{F} /\left(l_{F}+l_{J}\right)
$$

四 14 に示すように，まず添板の効果を確認するため，フィンス チフナだけに添板を取り付けて構面外剛性を確認する。このとき， 図 7 に示す三角形要素 $\mathrm{A}$ と $\mathrm{C}$ の境界における回転バネ剛性 $k_{A C}$ は, (9.b) 式において添板の板厚を $t_{s p}=0$ として算出する. その後にガ セットプレートにも添板を取り付けて構面外剛性と降伏曲げ耐力を 確認する，ただし，構面外剛性はすべての試験体で確認するが，降 伏曲げ耐力は一部の試験体（No. 1, 2, 5, 7, 8, 9) について確認した.

また上述した実験に先立ち，高力ボルト摩擦接合部（ブレース側 接合部と添板）の曲げ剛性を図 15 に示す方法で別途確認した。図 16 は実験結果であり, 載荷点における荷重 $P_{C}$-変形 $w_{C}$ 関係である. 図中の点線は，接合部母材の曲げ剛性 $E I_{J}$ を有する等質等断面部材 の荷重一変形関係である. 図 16 より, 高力ボルト摩擦接合部の曲 げ剛性は，添板の効果で接合部母材の曲げ剛性より大きいが，その 差はわずか $7 \%$ 程度である.

\section{3 実験結果 \\ 4. 3.1 降伏耐力}

図 17 に, 標準ディテール 2（フィンスチフナが梁フランジまで到 達していない) 試験体で, 降伏耐力を確認したもの (No. 2, 5, 7, 8, 9) について, 構面外荷重 $P$-構面外変位 $w_{1}$ 関係を示す。図 17 に は，(12) 式による降伏耐力 ${ }_{G} P_{y}$ （太点線）と (14) 式による降伏耐 力 ${ }_{S} P_{y}$ (太実線), およびサイドスチフナが初期降伏した点（）
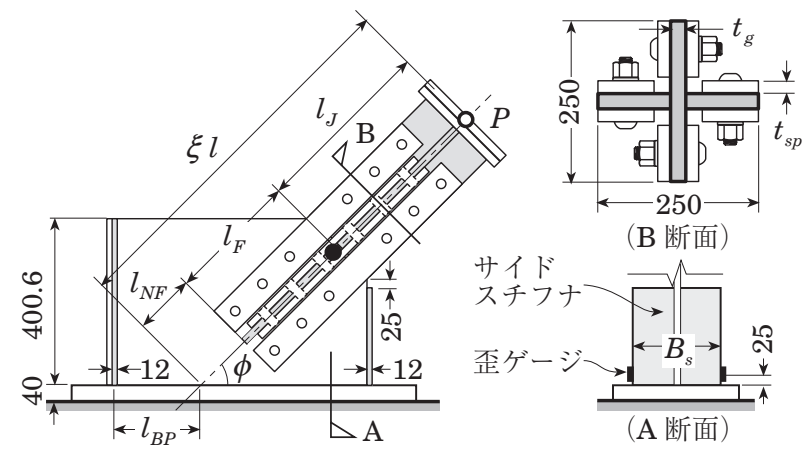

(B 断面)

\begin{tabular}{|c|c|c|c|c|c|c|c|c|}
\hline 試験体 & $\begin{array}{c}l_{N F} \\
(\mathrm{~mm})\end{array}$ & $\begin{array}{c}t_{g} \\
(\mathrm{~mm})\end{array}$ & $\begin{array}{c}t_{s p} \\
(\mathrm{~mm})\end{array}$ & $\begin{array}{c}l_{B P} \\
(\mathrm{~mm})\end{array}$ & $\begin{array}{c}B_{s} \\
(\mathrm{~mm})\end{array}$ & $\phi$ & $\begin{array}{l}\text { ボルト } \\
\text { 列数 }\end{array}$ & $\begin{array}{c}\xi l \\
(\mathrm{~mm})\end{array}$ \\
\hline No.1 & $0 *$ & \multirow{3}{*}{16} & \multirow{3}{*}{12} & \multirow{5}{*}{200} & \multirow{2}{*}{200} & \multirow{6}{*}{$45^{\circ}$} & \multirow{7}{*}{3} & \multirow{6}{*}{850} \\
\hline No. 2 & \multirow{3}{*}{170} & & & & & & & \\
\hline No.3 & & & & & 0 & & & \\
\hline No.4 & & \multirow{2}{*}{12} & \multirow{2}{*}{9} & & \multirow{5}{*}{200} & & & \\
\hline No.5 & 20 & & & & & & & \\
\hline No.6 & 170 & \multirow{4}{*}{16} & \multirow{4}{*}{12} & 0 & & & & \\
\hline No.7 & 110 & & & 115 & & $60^{\circ}$ & & 790 \\
\hline No.8 & \multirow{2}{*}{170} & & & \multirow{2}{*}{200} & & \multirow{2}{*}{$45^{\circ}$} & 4 & 1010 \\
\hline No.9 & & & & & 125 & & 3 & 850 \\
\hline
\end{tabular}

図 13 試験体の概要（単位：mm

表 2 試験体一覧

*フィンスチフナが端部まで到達している

表 3 鋼材の機械的性質

\begin{tabular}{|c|c|c|c|c|c|}
\hline 名称 & \multirow{2}{*}{ 鋼種 } & $\begin{array}{c}\text { 板厚 } \\
(\mathrm{mm})\end{array}$ & $\begin{array}{c}\text { 降伏点 } \\
\left(\mathrm{N} / \mathrm{mm}^{2}\right)\end{array}$ & $\begin{array}{c}\text { 引張強さ } \\
\left(\mathrm{N} / \mathrm{mm}^{2}\right)\end{array}$ & $\begin{array}{c}\text { 伸び } \\
(\%)\end{array}$ \\
\hline \multirow{2}{*}{$\mathrm{PL}-9$} & \multirow{3}{*}{ SN490B } & 8.93 & 379 & 536 & 25 \\
\cline { 1 - 4 } $\mathrm{PL}-12$ & 11.9 & 360 & 519 & 26 \\
\cline { 1 - 4 } $\mathrm{PL}-16$ & & 15.9 & 358 & 515 & 27 \\
\hline
\end{tabular}

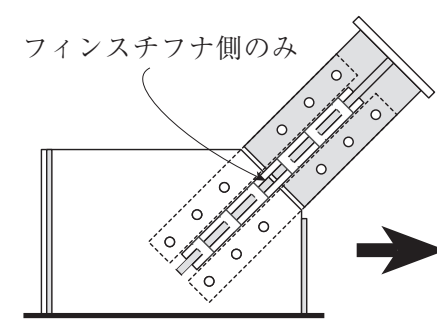

(構面外剛性の確認)
(構面外剛性・降伏曲げ耐力の確認) 図 14 載荷手順

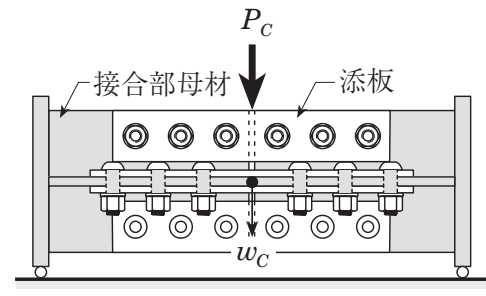

図 15 高力ボルト摩擦接合部の載荷実験

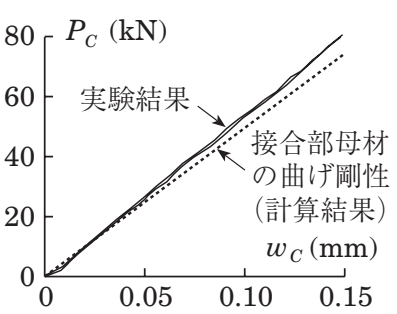

図 16 荷重一変形関係 


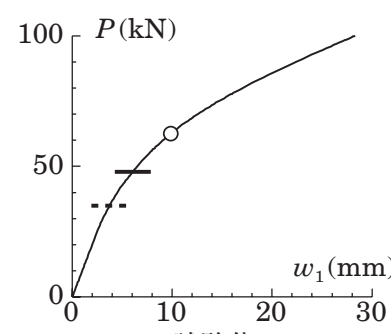

(a) 試験体 No.2

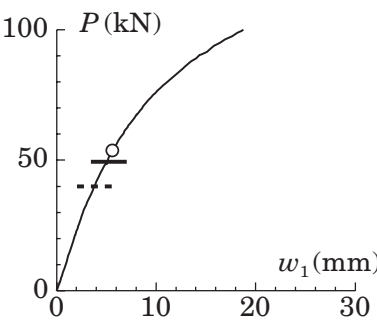

(c) 試験体 No.7

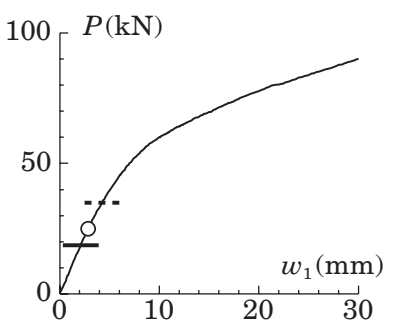

(e) 試験体 No.9

図 17 構面外荷重一構面外変形関傒

表 4 実験結果一覧（構面外剛性 $K_{C}^{*}$

\begin{tabular}{|c|c|c|c|c|c|}
\hline \multirow{2}{*}{ 試験体 } & \multicolumn{3}{|c|}{ 添板なし } & \multicolumn{2}{|c|}{ 添板あり } \\
\cline { 2 - 5 } & RBSM & FEM & $\begin{array}{c}\text { TEST } \\
\text { TEST }\end{array}$ & $\begin{array}{c}\text { RBSM } \\
\text { (kN/mm) }\end{array}$ & $\begin{array}{c}\text { TEST } \\
\text { TEST } \\
(\mathrm{kN} / \mathrm{mm})\end{array}$ \\
\hline No.1 & $0.93^{* 1}$ & 0.88 & 64.96 & $0.90^{* 1}$ & 66.56 \\
\hline No.2 & 0.77 & 0.80 & 6.80 & 0.78 & 10.09 \\
\hline No.3 & 0.76 & 0.80 & 2.40 & 0.68 & 2.68 \\
\hline No.4 & 0.66 & 0.78 & 3.33 & 0.65 & 5.16 \\
\hline No.5 & 0.63 & 0.64 & 6.07 & 0.72 & 8.01 \\
\hline No.6 & 0.80 & 0.83 & 8.28 & 0.76 & 12.23 \\
\hline No.7 & 0.95 & 0.97 & 7.67 & 0.94 & 10.54 \\
\hline No.8 & 0.90 & 0.90 & 6.08 & 0.90 & 9.23 \\
\hline No.9 & 0.81 & 0.77 & 6.43 & 0.91 & 8.66 \\
\hline
\end{tabular}

”1 接合部母材の構面外剛性

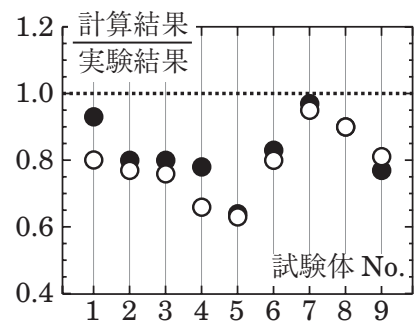

(a) 添板な ᄂ

図 $18 K_{G}^{*}$ の比較

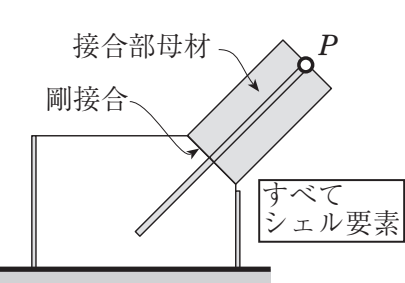

図 19 FEM 解析モデル概要

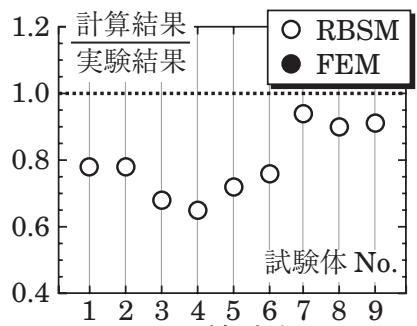

(b) 添板あり

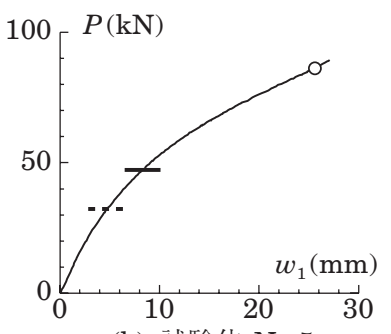

(b) 試験体 No.5

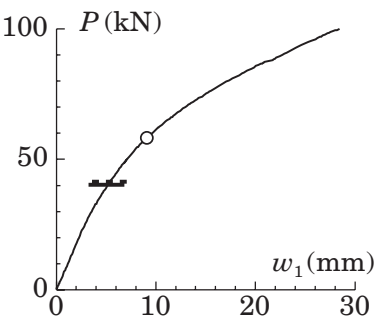

(d) 試験体 No.8
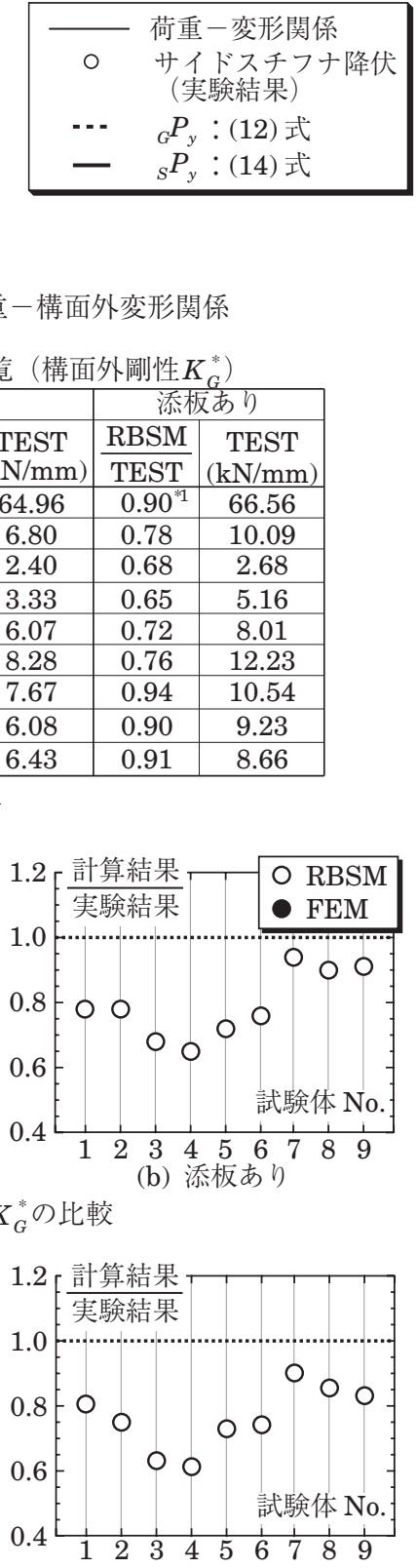

図20 $E I_{J}^{*}$ の比較
を併記している。サイドスチフナの初期降伏発生は, サイドスチフ ナに添付した歪ゲージ（図 13 参照）の計測值を，サイドスチフナ 下端部の歪に換算した值に基づいて判定している.

図 17 より，試験体 No. 5（図 13 の $l_{N F}$ を最小限にした試験体） を除いて，(14) 式による降伏耐力 ${ }_{S} P_{y}$ の計算值はサイドスチフナ降 伏時の構面外荷重（○）とよい対応を示していること, 降伏耐力の 計算值 ${ }_{S} P_{y}$ はガセットプレート接合部の弾性限界を概放捉えている ことがわかる。なお，図 17 (b) に示すように，試験体 No. 5 のサイ ドスチフナ降伏時の構面外荷重 $(\mathbf{0})$ が (14) 式の降伏耐力 ${ }_{S} P_{y}$ (実線) を大きく上まわっているのは，ガセットプレートの降伏（点線）が サイドスチフナの降伏（実線）よりも先に生じることに起因してい る。ただし，(14) 式の降伏耐力 ${ }_{S} P_{y}$ が実験結果を下まわっているの で，サイドスチフナを設計する上では安全側となる。これらのこと から，ガセットプレート接合部に作用する構面外の曲げモーメント は, サイドスチフナが負担すると考えることができ, ガセットプレー 卜接合部を弾性域に保つためには ${ }_{S} P_{y}$ に基づいてサイドスチフナの 寸法を決定すればよいといえる.

\subsection{2 剛性}

構面外剛性 $K_{G}^{*}$ につて, 実験結果を図 18 に，実験結果一覧を 表 4 に示す. 図 18 の縦軸は RBSM による計算結果 ${ }_{c a l} K_{G}^{*}((15)$ 式) を実験結果 ${ }_{\text {exp }} K_{G}^{*}$ (降伏耐力の計算值の $1 / 3$ の点における割線剛性) で無次元化したもので, 横軸は試験体 No. である. ただし, 試験体 No. 1 については，ガセットプレート接合部の構面外曲げ剛性が接 合部母材の構面外曲け剛性に等しいものとして ${ }_{c a l} K_{G}^{*}$ を計算してい る。また，図 18 や表 4 で"添板なし"は添板をフィンスチフナだ けに取り付けた場合を意味し，"添板あり"はガセットプレートに も取り付けた場合を意味する。

図 18, 表 4 より, RBSM による構面外剛性の計算結果 ${ }_{c a l} K_{G}^{*}$ は, 実験結果 ${ }_{\text {exp }} K_{G}^{*}$ を 1 割 $\sim 4$ 割程度過小評価するが, 算定式の簡易さ を考慮すれば十分な精度といえる，また，フィンスチフナが端部ま で到達していない試験体 No.2～No.9（標準ディテール 2）の構面 外剛性は，試験体 No.1（標準ディテール 1）の構面外剛性の高々 $15 \%$ 程度であることがわかる。このことから，接合部母材と同等 以上の曲げ剛性を接合部に確保するためには，標準ディテール 1 を 採用すべきであるといえる。

また，図 18 と表 4 には FEM 解析結果を併記している（ただし， " 添板なし"の場合のみ). FEM 解析には解析プログラム ADYNA を用い，節点の間隔は約 $25 \mathrm{~mm}$, 節点数は約 1500 点とし，板厚方 向に 1 層のシェル要素でモデル化している. 図 19 の解析モデルで は，接合部母材をガセットプレートおよびフィンスチフナに剛接合 し，添板，ボルト孔欠損，溶接部の余盛を無視している.

図 18 と表 4 によれば，FEM 解析結果は RBSM による計算結果 とほぼ一致している.すなわち,節点を 6 点だけ設けたRBSMであっ ても, FEM と同程度の精度で構面外剛性が求められるといえる。

図 20 には, (10) 式による座屈拘束ブレース接合部の構面外曲げ 剛性 $E I_{J}^{*}$ と実験結果（ただし，"添板あり"の場合のみ）を比較し て示す。図 20 の縦軸は (10) 式による計算值を実駼結果で除したも のであり，横軸は試験体 No. である。ただし，接合部の構面外曲げ 剛性の実験結果は, 載荷点の構面外変位を $w$ として, 次式で算定 


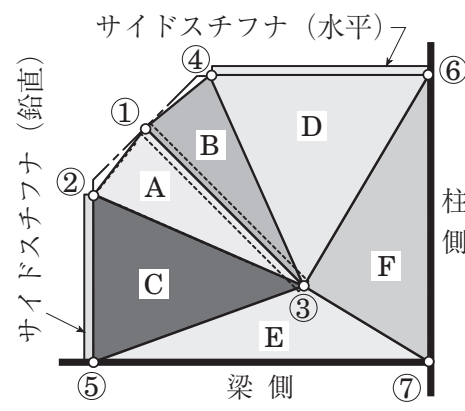

図 21 解析モデル

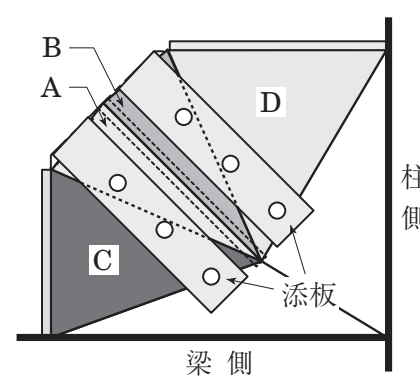

図 22 添板の配置
している.

$$
E I_{J}^{*}=P(\xi l)^{3} / 3 w
$$

図 20 より, $K_{G}^{*}$ の場合と同様に, (10) 式による座屈拘束ブレー ス接合部の構面外曲げ剛性 $E I_{J}^{*}$ の計算結果は, 実験結果を 1 割 $~ 4$ 割程度過小評価していることがわかる.

\section{5. 柱梁接合部側ガセットプレート接合部の構面外剛性と降伏耐力} 本章では, 柱梁接合部側のガセットプレート接合部を対象にして, 3 章と同様の方法を用いて, 接合部の構面外剛性と降伏曲げ耐力の 算定方法を示す.

\section{1 構面外剛性}

柱梁接合部側のガセットプレート接合部では, 図 21 に示すよう に, 水平方向にもサイドスチフナが設けられる場合を対象とする. この接合部の構面外剛性を求めるために, ガセットプレートを図 21 に示すように 6 つの三角形要素 $(\mathrm{A} \sim \mathrm{F})$ に分割する．節点(5) 〜 (7)は不動点なので, K ブレース交点側のガセットプレート接合部 の場合と同様に, $4 \times 4$ の全体剛性マトリックス $\boldsymbol{K}_{\boldsymbol{G}}$ が求められる. サイドスチフナの板厚がガセットプレートの板厚と同厚であり, 幅 (奥行き) が梁幅程度確保されている場合には, 節点(1)に作用する 構面外荷重 $P_{1}$ と構面外変位 $w_{1}$ の比 $K_{G}$ は (7) 式で与えられる. た
だし，図 22 に示すように，三角形要素 $\mathrm{A}$ と C の境界における回転 バネ剛性 $k_{A C}$, および三角形要素 $\mathrm{B}$ と D の境界における回転バネ 剛性 $k_{B D}$ に, 添板の効果を反映させるために, $k_{B D} に$ に (9.c) 式の代 わりに次式を用いる.

$$
k_{B D}=\frac{2 l_{34}}{{ }_{B D} h_{B}+_{B D} h_{D}} \cdot \frac{E\left(t_{g}^{3}+2 t_{s p}^{3}\right)}{12\left(1-v^{2}\right)}
$$

接合部全体の構面外曲げ剛性 $E I_{J}{ }^{*}$ は $\mathrm{K}$ ブレース交点側と同様に (7) 式を(10) 式に代入して求められる.

図 23 に, (10) 式による接合部の構面外曲げ剛性 $E I_{J}^{*}$ を, K ブレー ス交点側と柱梁接合部側のそれぞれについて例示する．対象とする 接合部は図 24 に示すものである. 図 23 の縦軸は, $E I_{J}^{*}$ を接合部 母材 $\left(+-250 \times 250 \times t_{g}\right)$ の曲げ剛性 $E I_{J}$ で無次元化したもの で, 横軸はフィンスチフナと梁フランジとの隙間 $l_{N F}$ (図 24 参照) である. 図 23 より, Kブレース交点側の接合部の構面外曲げ剛性は, 柱梁接合部側の接合部の構面外曲げ剛性の半分程度で, 接合部母材 の曲げ剛性 $E I_{J}$ よりかなり小さいといえる.

\section{2 降伏曲げ耐力}

4.3.1 節で述べたように, 柱梁接合部側のガセットプレート接合 部に拈いても, 構面外の曲げモーメントはすべてサイドスチフナが 負担すると考える，ただし，ガセットプレート接合部の降伏曲げ耐 力 ${ }_{S} M_{y}$ の算定にあたっては, 水平方向と鉛直方向のサイドスチフ ナのうち剛性の高い方が応力負担が大きいことを考慮して, (13) 式 の ${ }_{S} P_{y}$ に次式を用いる (各記号は図 25 参照).

$$
{ }_{s} P_{y}=\max \left(\frac{B_{s}^{2} t_{s} \sigma_{s y}}{6 h_{V}}, \frac{B_{s}^{2} t_{s} \sigma_{s y}}{6 h_{H}}\right)
$$

\section{6. ガセットプレート接合部の設計}

\section{1 設計用応力}

図 26 に示すように, 座屈拘束ブレース付構面の直交構面の層間

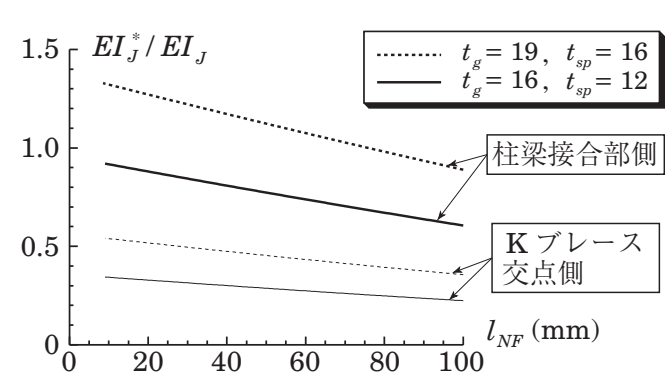

図 23 接合部の構面外曲げ剛性

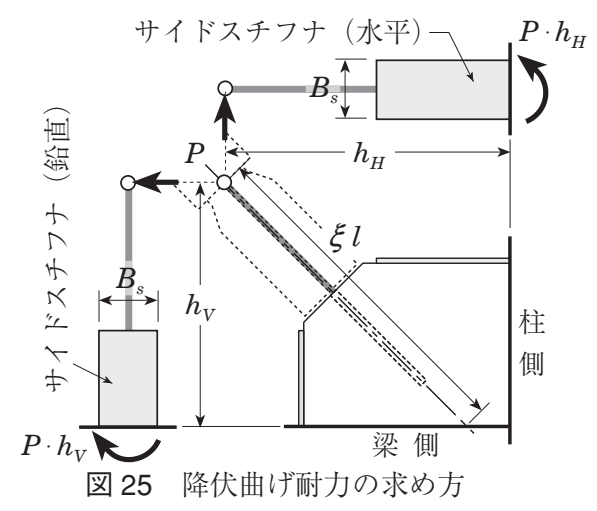

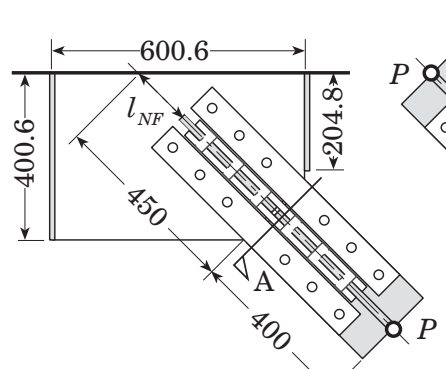

(a) K ブレース交点側 y

図 24 検討ディテール (単位： $\mathrm{mm}$ )

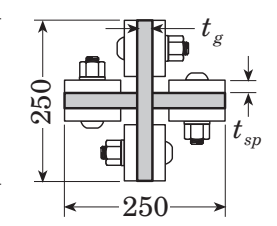

(c) A 断面

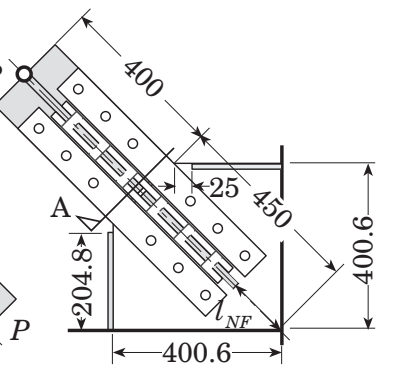

(b) 柱梁接合部側

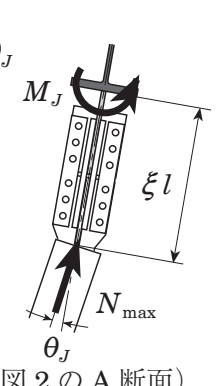

(図 2 の $\mathrm{A}$ 断面)

(c) 接合部に生じる 曲げモーメント (a) 直交構面の層間変形 (b) 座屈拘束 ブレースの変形

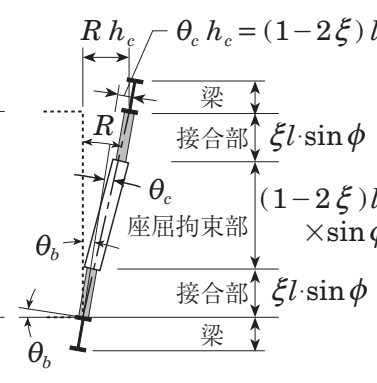

図 26 直交構面の層間変形に伴う座屈拘束ブレースの変形

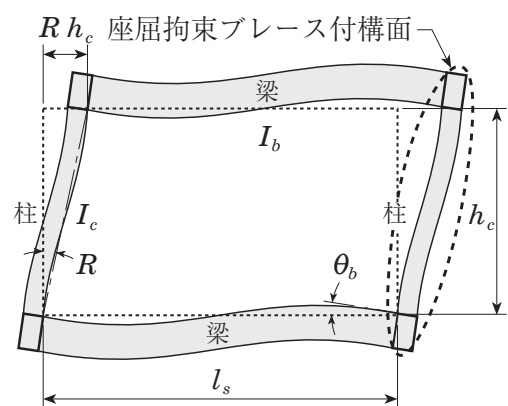




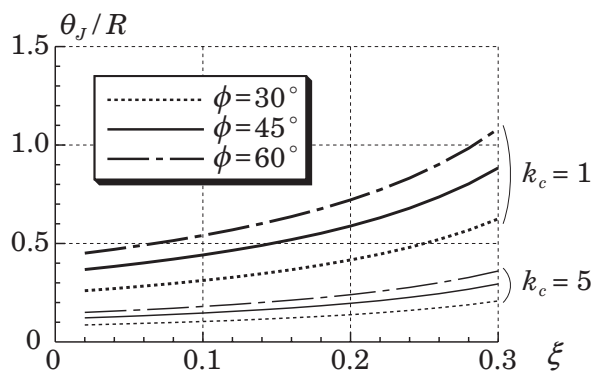

図 27 接合部と芯材のなす角 $\theta_{J}$

変形が生じると，ガセットプレート接合部端部には構面外の曲げ モーメント $N_{\max } \xi l \theta_{J}$ が作用する.ここで, $N_{\max }$ は座屈拘束ブレー スの設計用最大軸力， $\theta_{J}$ は図 26(c) に示すように図 2 の A 方向か ら見たときの軸力の作用線と接合部のなす角度であり, 芯材と座屈 拘束材の間の隙間を無視すると， $\theta_{J}$ は図 $26(\mathrm{~b})$ を参照して次式で 求められる。

$$
\theta_{J}=\frac{h_{c} \theta_{c}}{(1-2 \xi) l}=\frac{\theta_{c} \sin \phi}{1-2 \xi}
$$

ただ， $\phi$ は座屈拘束ブレースの取付角度である。また，図 $26(\mathrm{~b})$ の $\theta_{c}$ と $\theta_{b}$ は, 直行構面内における柱端の節点回転角および梁端の 節点回転角であり， $\theta_{c}$ は以下の考え方に基づいて算定する.

図 26 (a)に示すように，座屈拘束ブレース付構面の直交構面に層 間変形角 $R$ が生じた状態を考える。ただし, 図 26 の骨組では, 柱 と梁は弾性を保ち, 左右の柱の曲げ剛性, および上下の梁の曲げ剛 性はそれぞれ等しいものとし，座屈拘束ブレース接合部は剛と考え ている。また，図中の記号は以下のように定義している．

$$
\begin{array}{ll}
\cdot l_{s}: \text { 梁の内法長さ } & \cdot h_{c} \text { : 柱の内法高さ } \\
\cdot I_{b} \text { : 梁の断面 } 2 \text { 次モーメント } & \cdot I_{c} \text { : 柱の断面 } 2 \text { 次モーメント }
\end{array}
$$

ここで, 柱梁剛比を $k_{c}=\left(I_{c} / h_{c}\right) /\left(I_{b} / l_{s}\right)$ として, $\theta_{c}$ と $R$ には以下の 関係を用いる。

$$
\theta_{c}=\frac{R}{k_{c}+1}
$$

(20) 式を (19) 式に代入すると $\theta_{J}$ が求められる。図 27 は, (19) 式 で得られる $\theta_{J}$ と $\xi$ の関係である。図より， $\theta_{J}$ は直交構面の層間変 形角 $R$ より小さく， $\theta_{J}=R$ と考えれば接合部設計用の曲げモーメ ントを過大評価することになる。

(19) 式の $\theta_{J}$ は接合部を剛と見なした場合であるが，実際には剛 ではないから，接合部設計用の曲げモーメント $M_{J}$ は，拡大係数を 乗じて次式で与えるものとする.

$$
\begin{aligned}
& M_{J}=\frac{N_{\max } \xi l \theta_{J}}{1-N_{\max } /{ }_{p} N_{c r}} \\
& \text { ただし, }{ }_{p} N_{c r}=(1-2 \xi) \pi^{2} E I_{J}^{*} /(2 \xi l)^{2}
\end{aligned}
$$

\section{2 ガセットプレート接合部の設計}

4.3.1 節の検討結果より，標準ディテール 2 の場合，(21) 式で表 される接合部設計用の曲げモーメント $M_{J}$ は, サイドスチフナで負 担されるものと考えることができる。したがって， $M_{J}$ に対して接 合部が弾性を保つための条件を次式で与える.

$$
\frac{M_{J}}{{ }_{S} M_{y}}<1
$$

ここで，ガセットプレート接合部の降伏曲げ耐力 ${ }_{S} M_{y}$ は (13) 式に よって算定する.
一方，標準ディテール 1 の場合は，フィンスチフナが塑性化する とガセットプレート接合部の曲げ剛性が急激に低下するので，次式 を満たすように設計しなければならない。

$$
\frac{N_{\max }}{{ }_{G} N_{y}}+\frac{M_{J}}{{ }_{G} M_{y}}<1
$$

ここで， ${ }_{G} N_{y}$ はガセットプレート接合部の降伏軸力, ${ }_{G} M_{y}$ はガセッ トプレート接合部の降伏曲げモーメントである。標準ディテール 1 の場合，ガセットプレート接合部の耐力は接合部母材 (図 3 参照) の耐力と同等以上とみなせるので, ${ }_{G} N_{y}$ および ${ }_{G} M_{y}$ は接合部母材の 幅 $B_{j}$, 板厚 $t_{j}$, 降伏応力 $\sigma_{j y}$ を用いて次式で求める.

$$
\begin{aligned}
& { }_{G} N_{y}=\left(2 B_{j}-t_{j}\right) t_{j} \sigma_{j y} \\
& { }_{G} M_{y}=\frac{\left(B_{j}^{3} t_{j}+B_{j} t_{j}^{3}-t_{j}^{4}\right) \sigma_{j y}}{6 B_{j}}
\end{aligned}
$$

\section{7. 結論}

本論では, 座屈拘束ブレース芯材の塑性化に伴って座屈拘束部の 両端がヒンジとみなせ，フィンスチフナが梁フランジまで到達して いないガセットプレート接合部を有する場合（標準ディテール 2) を対象として，剛体一バネモデルを用いた座屈拘束ブレース接合部 の構面外曲げ剛性と降伏耐力の算出方法を示し，その結果を載荷実 験結果と比較した。また，ガセットプレート接合部に作用する構面 外の曲げモーメントの算出方法を示し，ガセットプレート接合部の 設計法を提案した。本論で得られた知見を以下に要約して記す。

[1] ガセットプレート接合部が弾性を保つためには，接合部に作用 する構面外の曲げモーメント（(21) 式）に対して，(23) 式また は (24) 式を満足するように設計しなければならない。ただし， 芯材と座屈拘束材の間の隙間が (21) 式に及ぼす影響について は課題として残されている.

[2] 座屈拘束ブレース接合部の設計に必要な構面外曲げ剛性は (10) 式によって，また降伏曲げ耐力は (13) 式によって算定できる.

[3] 接合部の構面外曲げ剛性の計算值は，実験結果を 1 割〜 4 割程 度過小評価する。また，降伏曲げ耐力の計算值は，ガセットプ レート接合部の弾性限界を概ね捉えている.

[4] K ブレース交点側のガセットプレート接合部では，標準ディ テール2（図 3(b) 参照）の構面外曲げ剛性と降伏曲げ耐力が, 標準ディテール 1 （図 3 (a) 参照）に比べて非常に小さい。し たがって，Kブレース交点側のガセットプレート接合部には標 準ディテール 1 を採用すべきである.

\section{謝辞}

本研究を遂行するにあたり，JFE 技研（株）加村久哉 氏，石井 匠氏, JFE スチール (株) 清水孝憲氏に貴重なご意見を賜りました. また，剛体一バネモデル（RBSM）について，(独）防災科学技術 研究所 招聘研究員 井根達比古 氏にご指導いただきました。ここに 記して感謝の意を表します。

\section{参考文献}

1) 天畠秀秋, 聲高裕治, 井上一朗：接合部を含む座屈拘束ブレースの構面外 座屈荷重, 日本建築学会構造系論文集，第 581 号，pp.127-134，2004.7

2) 木下智裕，聲高裕治，井上一朗，飯谷邦祐：接合部を含む座屈拘束ブ レースの構面外座屈防止条件, 日本建築学会構造系論文集, 第 621 号, pp.141-148，2007.11 
3) 竹内 徹, 山田 哲, 北川まどか, 鈴木一弁, 和田 章: 構面外剛性の低 い接合部により接合された座屈拘束ブレースの座屈安定性, 日本建築学会 構造系論文集，第 575 号, pp.121-128, 2004.8

4) Lin, M. L., Tsai, K. C., and Tsai, C. Y.: Bi-directional sub-structural pseudo-dynamic tests of a full-scale 2-story BRBF, Part 2: Compressive behavior of gusste plates, Proceedings of the 8th U.S. National Conference on Earthquake Engineering, Paper No. 1642, 2006.4

5) Tsai, K. C., Hsiao, P. C., Lin, S. L., and Lin, K.C.: Overview of the Hybrid Tests of A Full Scale 3-Bay 3-Story CFT/BRB Frame, 4th International Symposium of Steel Structures, pp.73-84, 2006.11

6) 吉敷祥一, 市川 康, 山田 哲, 和田 章: ガセットプレート接合部に着 目した部分架構の実験 ダンパーを組み込んだ勒性架構の総合的な耐震性 能の向上その 1 , 日本建築学会構造系論文集, 第 620 号, pp.133-140, 2007.10

7) 川井忠彦, 近藤一夫 : 新しい離散化モデルによる板の曲げ崩壊解析，日本 造船学会論文集，第 142 号, pp.190-196, 1977.12

\section{付録 1 . 三角形要素の寸法の算定}

本論で提案した標準ディテール 2 のガセットプレート接合部の構 面外剛性（(7) 式）は，図 5 または図 21 の解析モデル中の三角形 要素の寸法を用いて算定することができる，以下には，図 A-1 に示 すガセットプレートの外形寸法を用いて，図 5 および図 21 の各三 角形要素の寸法を算定する方法を示す.

[i] K ブレース交点側のガセットプレート接合部

$$
\begin{aligned}
& l_{13}=l_{F} \\
& l_{23}=\sqrt{\left\{l_{F}-\left(h_{e}-h_{s V}\right) \sin \phi\right\}^{2}+{ }_{A B} h_{A}^{2}} \\
& l_{34}=\sqrt{\left(l_{F}-w_{e} \cos \phi\right)^{2}+{ }_{A B} h_{B}^{2}} \\
& { }_{A B} h_{A}=\frac{h_{c}-h_{e}}{2 \cos \phi}+\left(h_{e}-h_{s V}\right) \cos \phi \\
& { }_{A B} h_{B}=\frac{h_{c}-h_{e}}{2 \cos \phi}+w_{e} \sin \phi
\end{aligned}
$$

(a) K ブレース交点側

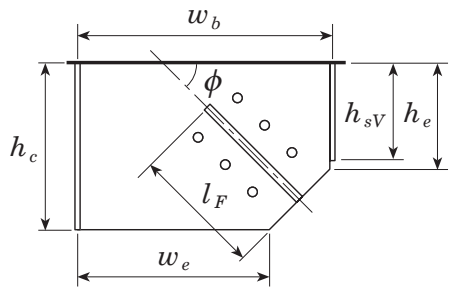

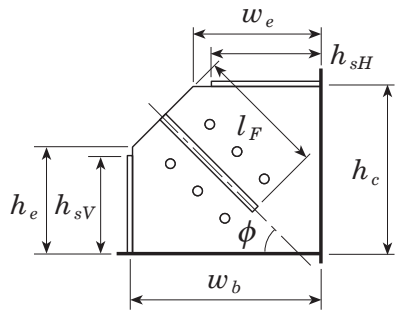

(b) 柱梁接合部側
図A-1ガセットプレート接合部の寸法

$$
\begin{aligned}
{ }_{A C} h_{A} & =\frac{l_{F}}{l_{23}}{ }_{A B} h_{A} \\
{ }_{A C} h_{C} & =\frac{h_{s V}}{l_{23}}\left\{\frac{w_{b}-w_{e}}{2}+l_{F} \cos \phi\right\} \\
{ }_{B D} h_{B} & =\frac{l_{F}}{l_{34}}{ }_{A B} h_{B} \\
{ }_{B D} h_{D} & =\frac{h_{c}}{l_{34}}\left\{\frac{w_{b}+w_{e}}{2}-l_{F} \cos \phi\right\}
\end{aligned}
$$

[ii] 柱梁接合部側のガセットプレート接合部

柱梁接合部側のガセットプレートでは, (A-3) 式, (A-5) 式, (A-8) 式，(A-9) 式の代わりに次式を用いる.

$$
\begin{aligned}
& l_{34}=\sqrt{\left\{l_{F}-\left(w_{e}-h_{s H}\right) \cos \phi\right\}^{2}+{ }_{A B} h_{B}^{2}} \\
& { }_{A B} h_{B}=\frac{h_{c}-h_{e}}{2 \cos \phi}+\left(w_{e}-h_{s H}\right) \cos \phi \\
& { }_{B D} h_{B}=\frac{l_{F}}{l_{34}}{ }_{A B} h_{B} \\
& { }_{B D} h_{D}=\frac{h_{s H}}{l_{34}}\left\{\frac{h_{c}-h_{e}}{2}+l_{F} \sin \phi\right\}
\end{aligned}
$$

